\title{
PRODUCTION AND CHARACTERIZATION OF MONOCLONAL ANTIBODIES SPECIFIC FOR
} PSEUDORABIES VIRUS

\author{
MARKOVIĆ LJILJANA*, AŠANIN RUŽICA**, RADOJIČIĆ SONJA** and ISENOVIĆ ESMA* \\ *Institute of Nuclear Sciences "Vinča", Laboratory for Radiobiology and molecular genetic, Belgrade \\ ${ }^{*}$ Faculty of Veterinary Medicine, University of Belgrade
}

(Received 14. April 2007)

Monoclonal antibodies (MAbs) against Pseudorabies virus (PrV) were obtained by the fusion of P3x-Ag8.653 myeloma and spleen cells from immunized BALB/c mice with a suspension of Pseudorabies (PrV) virus strains: MAVE (Morbus Aujeszk'y virus Ercegovac) and NS 257 (Novosadski virus strain). A total of 95 antibody-secreting hybridoma cells against the virus strain (MAVE and NS 257) of Pseudorabies virus have been isolated. Ten of these monoclonal antibodies were found by ELISA (Enzyme-linked immunosorbent assay) to react specifically with both virus strains. MAbs for VAM 2.1, VAM 4.1, VAM 5.1 and VAM 6.1 were purified by chromatography on protein G Sepharose 4FF and they have been shown to have a strong reactivity in the ELISA test. All MAbs were characterized by electrophoresis SDS-PAGE and electrophoresis Western-blot immunoassay. MAbs VAM 2.1, VAM 4.1, VAM 5.1 and VAM 6.1 in hybridoma culture supernatants and ascites fluid were quantified using a dot-blot immunobinding assay. The VAM 2.1 MAb was found to be more specific in the reaction with viruses of both strains. The glycoprotein of $40 \mathrm{kD}$ molecular weight was found on the surface of virus strain MAVE. Results showed that the produced and characterized MAbs against PrV strains can be used for the detection of Aujeszky's disease.

Key words: Pseudorabies virus, monoclonal antibodies, MAVE strain, NS 257 strain, ELISA

\section{INTRODUCTION}

Pseudorabies is an acute, frequently fatal disease affecting most species of domestic and wild animals. The causative agent of the disease is Pseudorabies virus (PrV) a member of Herpesviridae family, a sub-family of Alphaherpesvirine, along with herpes simplex virus types 1 (HSV-1) and 2, varicella-zoster virus and bovine herpesvirus type 1 (Roizman, 1990). The disease is characterized by a variety of clinical signs; the most prominent involve the nervous and respiratory systems in swine (Wittman, 1986). 
Aujesky first recognized pseudorabies as a disease of cattle and dogs in Hungary in 1902. It soon became evident, that swine were the natural hosts of the virus and could also die as a result of the disease. Pseudorabies has been recognized for death in swine of all ages and as a cause of abortion. In the United States the disease caused a variety of clinical manifestations, including death of newborn and adult swine and fetal death with abortions in pregnant swine, cattle, sheep, dogs and cats.

Piglets up to 3 weeks of age may suddenly die with signs of fever, loss of appetite, diarrhea, vomiting, incoordination, and concurrent convulsions. Pigs 3 weeks to 5 months old usually develop a degree of resistance to the disease. The disease in adult pigs often is characterized by fever, respiratory and nervous signs. Sows infected in early pregnancy may resorb the fetuses during pregnancy. Sows infected in middle pregnancy may abort mummified fetuses.

Swine recovery from pseudorabies confers resistance for at least 12 months. Re-exposure may result in reinfection, but it is usually asymptomatic. The passive immunity passed on from an immune sow through the colostrum may protect the piglets for 5 to 10 weeks. However, passive immunity may be too low to protect the piglets.

Vaccines have been used in Europe for years and in the United States since 1977. However, researchers consensus is that vaccines reduce swine losses and spread of the disease, but do not totally prevent infection. In other conditions vaccines have been reported to enhance the control of pseudorabies. Current vaccines stimulate an antibody response indistinguishable by serologic tests from that, resulting from the virulent virus and will hinder any control or eradication program.

Clinical signs of pseudorabies are variable so clinical diagnosis should always be confirmed by laboratory tests. Four tests have been approved for the diagnosis of pseudorabies (the Serum-Virus Neutralization Test (SN), Virus Isolation (VI), Fluorescent Antibody Tissue Section Tests (FATS), and the Enzyme Linked Immune-Sorbent Assay (ELISA). Other tests (Dot ELISA, Western blot) are still being developed. The SN and ELISA are extremely reliable tests. While these tests accurately detect antibodies to pseudorabies, they do not differentiate between antibodies resulting from natural disease and those resulting from vaccination. Serum submitted for SN examination may be hemolyzed or contaminated with bacteria, thus rendering the $\mathrm{SN}$ test unreliable. The SN and ELISA tests can accurately detect antibodies to pseudorabies, but they do not differentiate between antibodies resulting from natural disease and those resulting from vaccination. Therefore, specific monoclonal antibodies (MAbs), if used together with other techniques, would be an alternative tool for a rapid and accurate diagnostic test for the early detection of Aujeszky's disease. (Eloit et al., 1989; Qvist et al., 1990; Zsak et al., 1992; Morenkov et al., 1999; Arce et al., 2002).

In the present study, we prepared a monoclonal antibody obtained from the hybridoma cell supernatant and ascites fluid, which recognizes the protein and thus we examined the presence of antigenes for both vaccine strains of PrV. 
Acta Veterinaria (Beograd), Vol. 57. No. 5-6, 441-451, 2007.

Marković Ljiljana et al.: Production and characterization of

\section{MATERIALS AND METHODS}

Virus strains: Our wild-type strains PrV NS 257 (Novosadski strain) and PrVMAVE (Morbus Aujeszky's Ercegovac virus) were propagated on chicken fibroblast cells. Virus isolates were grown in Dulbecco's modified Eagle's medium (DMEM) supplemented with $5 \%$ foetal bovine serum (FCS) and 100 units $/ \mathrm{mL}$ penicillin and $100 \mu \mathrm{g} / \mathrm{mL}$ streptomycin. (Lowry et al., 1985; Milić et al., 1994).

Production of monoclonal antibodies from hybridoma cells: Female BALB/c mice were immunized intraperitoneally with PrV antigen. Ten, 25 and, 28 days later, mice were injected with $0.2 \mathrm{~mL}$ of the same antigen. Splenocytes were fused with P3x-Ag8.653 myeloma cells line, following Kohler et al. (1975). Hybridoma clones were selected for further characterization on the basis of antibody binding by ELISA. Cells from positive wells were cloned at least twice by limiting dilution. Monoclonal antibodies were determined by ELISA, using peroxidase conjugated goat anti-mouse IgG $(\mathrm{H}+\mathrm{L})$ (Sigma, St. Louis, USA).

Monoclonal antibody production from ascites fluid: Ascites fluid was produced by injecting $5 \times 10^{6}$ hybridoma cells into pristane-primed BALB/c mice and ascitic fluid was withdrawn after 10 and 14 days. MAbs were purified from ascites fluid by chromatography on protein G Sepharose 4FF (Protein G Sepharose 4 FF; Amersham Pharmacia, Uppsala, Sweden) according to manufacturer's instructions. The concentrations were determined spectrophotometrically, at $280 \mathrm{~nm}$.

ELISA screening assay: The polystirene microtiter plates (Nunc, Roskilde, Denmark) were coated with $100 \mu \mathrm{L}$ of the antigen solution tested species (MAVE and NS 257), overnight at $4^{\circ} \mathrm{C}$. Plates were then washed three times in phosphatebuffered saline containing $0.05 \%$ Tween 20 (PBST) and than were blocked by incubation with $100 \mu \mathrm{L} 1 \%$ bovine serum albumin (BSA, Sigma) for $1 \mathrm{~h}$ at room temperature (RT). After washing the hybridoma supernatant (100 $\mu \mathrm{L})$ was added and plates were incubated for $2 \mathrm{~h}$ at RT and then washed, and $100 \mu \mathrm{L}$ of the peroxidase conjugated goat anti-mouse IgG $(\mathrm{H}+\mathrm{L})$ (Sigma, St. Louis, USA) was added at a dilution of $1 / 1000$ in PBS and incubated for $1 \mathrm{~h}$ at RT. The final step of each assay was incubation with ABST substrate solution (2,2'azino-bis 3 ethylbenzthiazoline-6-sulfonic acid) (ICN, Biomedicals Inc. USA) and $0.03 \% \mathrm{H}_{2} \mathrm{O}_{2}$. Color development was stopped by adding $\mathrm{H}_{2} \mathrm{SO}_{4}$. Plates were read in an ELISA reader (Multiscan Plus, Labsystems, Finland) at $405 \mathrm{~nm}$.

Dot ELISA assay: Extract of antigenes (MAVE and NS 257) were applied on PVDF membranes Immobilon P (Millipore Corp., Bedford, MA, USA) with $0.45 \mu \mathrm{M}$ pores using the 96-well dot-blot block (Bio-Rad, Hercules, USA). The membranes were then removed and washed with Tris buffered saline (TBS) containing $0.1 \%$ bovine serum albumin and $0.05 \%$ Tween-20 (BSA-T) as the blocking solution. After incubation for $1 \mathrm{~h}$ at $37^{\circ} \mathrm{C}$ the membranes were then washed three times. The membrane sheets were incubated with a series of dilutions of the antigen at $37^{\circ} \mathrm{C}$ for $4 \mathrm{~h}$ and were washed again three times. After washing, the membranes were immersed in MAb supernatants for $1 \mathrm{~h}$ at room temperature. Further, the membranes reacted with horseradish peroxidase-conjugated goat anti-mouse $\lg G(\mathrm{H}+\mathrm{L})$ for $2 \mathrm{~h}$ at $\mathrm{RT}$ and were finally washed. The membranes were treated 
with 4-chloro-1-naphthol substrates (ICN, Biomedicals Inc. USA) for 15 min, and the color density was measured by a scanning densitometer (Cordosa et al., 1988; Yoshida et al., 1998; Sulimenko et al., 2004).

Gel electrophoresis and Western blot: The purified proteins were separated on $10 \%$ polyacrylamide gel (SDS-PAGE) as described by Laemmli (1970) and then transfered to a PVDF membrane Immobilon P (Millipore, Bedford, MA, USA) in a semi-dry blot chamber (Novablot, Bromma, Sweden) according to the method of Towbin et al. (1979). The blot membranes were cut, on strips and each strip was incubated for $2 \mathrm{~h}$ with MAbs. After washing, each strip was incubated for $1 \mathrm{~h}$ with peroxidase conjugated goat anti-mouse lg (Sigma). Recognized bands were stained by addition of 4-chloro-1-naphthol and $\mathrm{H}_{2} \mathrm{O}_{2}$ (Towbin et.al., 1979; Draber, 1991).

Statistical analysis was done by using Origin 6.0 software.

\section{RESULTS}

For the purpose of this study monoclonal antibodies were obtained by fusion of P3X-Ag8.653 cells with spleen cells of BALB/C mice intraperitoneally immunized with PrV virion (MAVE and NS 257 strains). Fusion mixtures (95) were obtained and tested by ELISA. The concentration of total antigen proteins prior to coating viral antigens onto microtitrating plates was determined by the Lowry method. Antigen concentration most frequently used for plates coating was $20 \mu \mathrm{g} / \mathrm{mL}$, based on the studies of Buttler (1991). In total were detected $9.5 \%$ hybrid supernatants based on the evaluation of the obtained optical density in ELISA. In further procedures they were titrated using 1/5 to 1/640 dilutions. On the

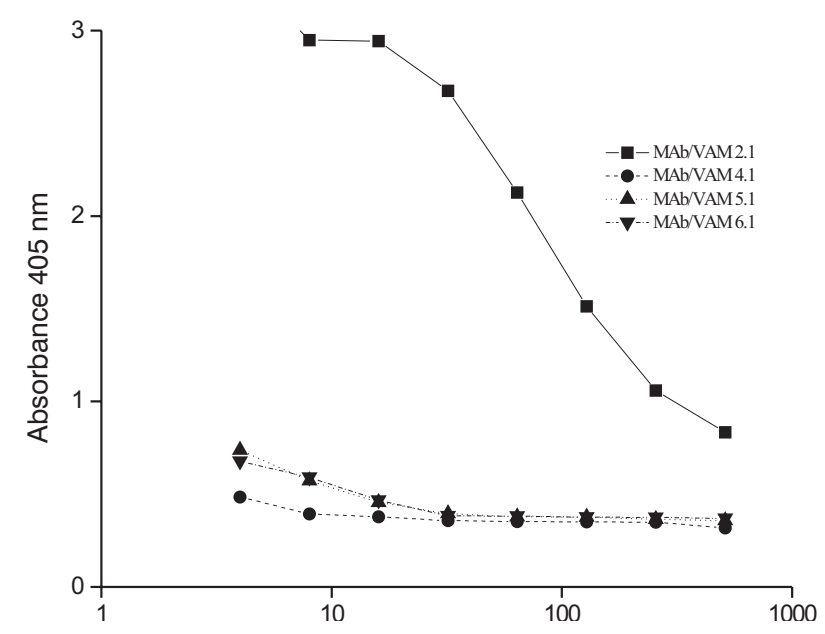

Figure 1. Analysis of hybridoma culture supernatant in ELISA. Plates were coated with an optimal concentration $(25 \mu \mathrm{g} / \mathrm{mL})$ of antigen NS 257 and the MAbs were titrated in serial two-fold dilution steps from 1:5 
Acta Veterinaria (Beograd), Vol. 57. No. 5-6, 441-451, 2007.

Marković Ljiljana et al.: Production and characterization of

monoclonal antibodies specific for pseudorabies virus

basis of preliminary tests, four MAbs (VAM 2.1, VAM 4.1, VAM 5.1, and VAM 6.1) were selected and used for further testing. Concurrently tested was the binding activity of selected supernatants with three different viral protein concentrations $(1 \mu \mathrm{g} / \mathrm{mL}, 5 \mu \mathrm{g} / \mathrm{mL}$ and $25 \mu \mathrm{g} / \mathrm{mL})$. The concentration of $25 \mu \mathrm{g} / \mathrm{mL}$ gave the best results in the reaction with the antigen coatings of MAVE and NS 257 strains. The comparative review of obtained results of the four tested hybridoma has shown (Figure 1 and 2) that VAM 2.1 was highly active and could be used for immunochemical testing.

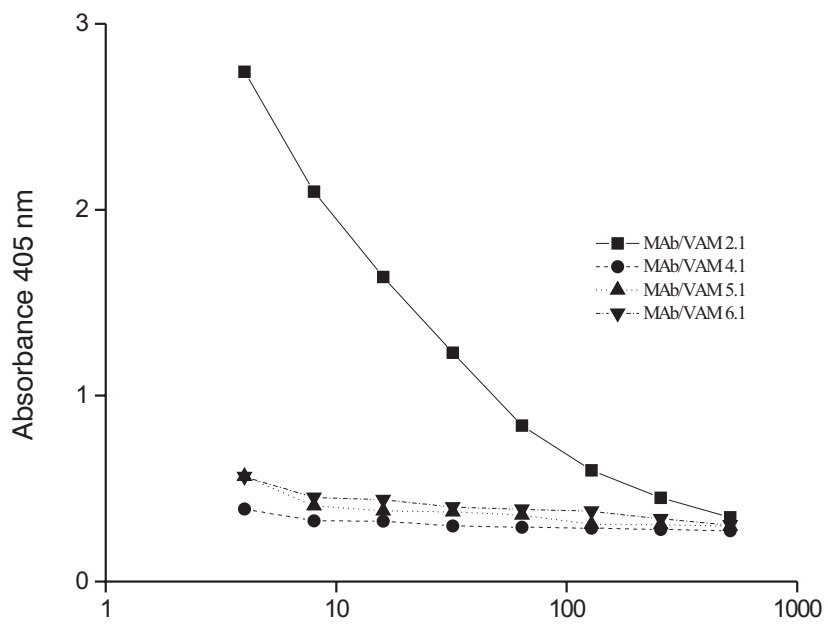

Figure 2. Analysis of hybridoma culture supernatant in ELISA. Plates were coated with an optimal concentration $(25 \mu \mathrm{g} / \mathrm{mL})$ of antigen MAVE and the MAbs were titrated in serial two-fold dilution steps from 1:5

Further experiments included testing of different viral protein concentrations with a constant quantity of antibodies (Table 1). Viral proteins were titrated in the dot-blot assay in a series of two-fold dilutions and coated on PVDF membranes. The obtained results show that the least concentration of $2.58 \mu \mathrm{g}$ is sufficient to perceive the binding activity of VAM 2.1 hybridoma supernatant with MAVE and NS 257 viral protein concentrations, which confirms their low activity.

Immunoglobulins isolated by affinity chromatography from ascites fluid confirm that they belong to IgG category. Their activity has been tested in ELISA and the results show that VAM 4.1, VAM 5.1 and VAM 6.1 have much higher optical densities than in hybridoma supernatants (Figure 3 and 4). Their binding reactions confirm specific interactions of rather low activity. The comparative test results show a significant activity of VAM 2.1 and confirm the findings of previous 
Table 1. Dot-blot results of MAbs reaction against two strains of PrV

\begin{tabular}{|c|c|c|}
\hline MAb & $\begin{array}{c}\text { Protein concentration } \\
\left(\mathrm{ng} / \mathrm{mm}^{2}\right) \text { MAVE }^{2}\end{array}$ & $\begin{array}{c}\text { Protein concentration } \\
\left(\mathrm{ng} / \mathrm{mm}^{2}\right) \text { NS } 257^{2}\end{array}$ \\
\hline \hline VAM 2.1 & 2.58 & 2.58 \\
\hline VAM 4.1 & 20.6 & 20.6 \\
\hline VAM 5.1 & 41.2 & 41.2 \\
\hline VAM 6.1 & 82.5 & 165 \\
\hline
\end{tabular}

Legend:

1 Purified monoclonal antibody

2 The strain MAVE or NS 257 was dotted onto nitrocellulose membrane, the reaction was tested and measured quantities expressed of purified protein in nanograms

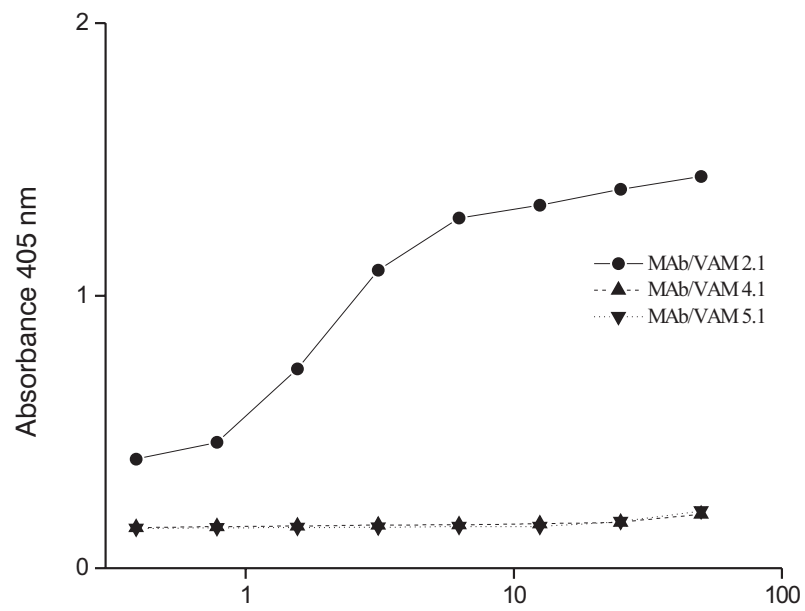

Figure 3. Titration of competing antibodies from ascites fluid at ELISA. The competing antibodies are MAbs against the antigen NS 257 in optimal concentration $(25 \mu \mathrm{g} / \mathrm{mL})$

analyses PrV envelope of MAVE and NS257 strains was electrophoretically separated (SDS-PAGE). Three different gel concentrations were used $(8 \%, 10 \%$ and $12 \%$ ). The best results were obtained on $10 \%$ gel with two-fold concentrations of coated antigens $(15 \mu \mathrm{g} / \mathrm{mL})$. NS antigen was separated on seven protein strips of different molecular weights (from $150 \mathrm{kD}$ to $25 \mathrm{kD}$ ) (Figure 5). The envelope of MAVE virus strain was separated on eleven strips having molecular weights from 25 to $150 \mathrm{kD}$. If compared, their protein fractions are equally distant from the inlet point into the separation gel. In MAVE strain a larger number of strips was observed in the zone of high molecular weights and one in a vaguely defined strip of $40 \mathrm{kD}$. Protein strips separated by Western blot immunoassay were transferred from the gel to the PVDF membrane. The efficiency of such transfer was then 
Acta Veterinaria (Beograd), Vol. 57. No. 5-6, 441-451, 2007.

Marković Ljiljana et al.: Production and characterization of

monoclonal antibodies specific for pseudorabies virus

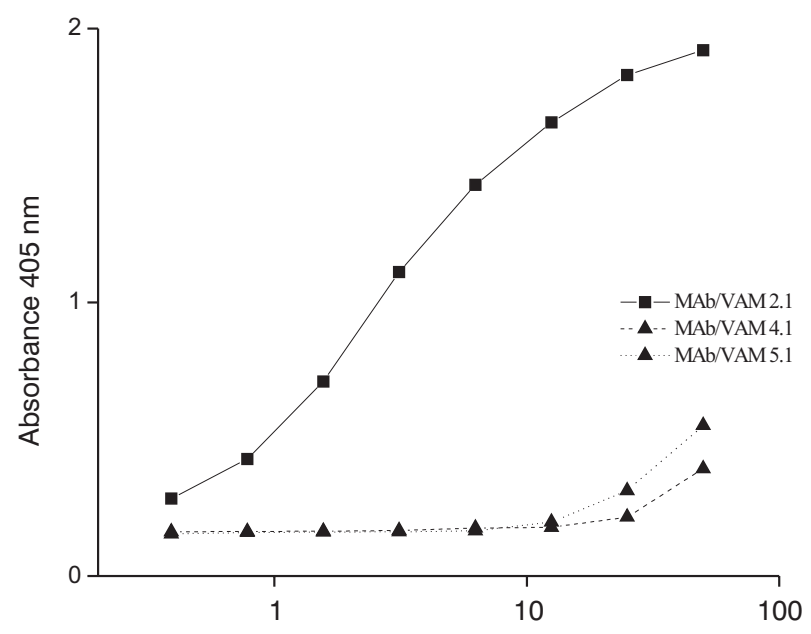

Figure 4. Titration of competing antibodies from ascites fluid at ELISA. The competing antibodies are MAbs against the antigen MAVE in optimal concentration $(25 \mu \mathrm{g} / \mathrm{mL})$

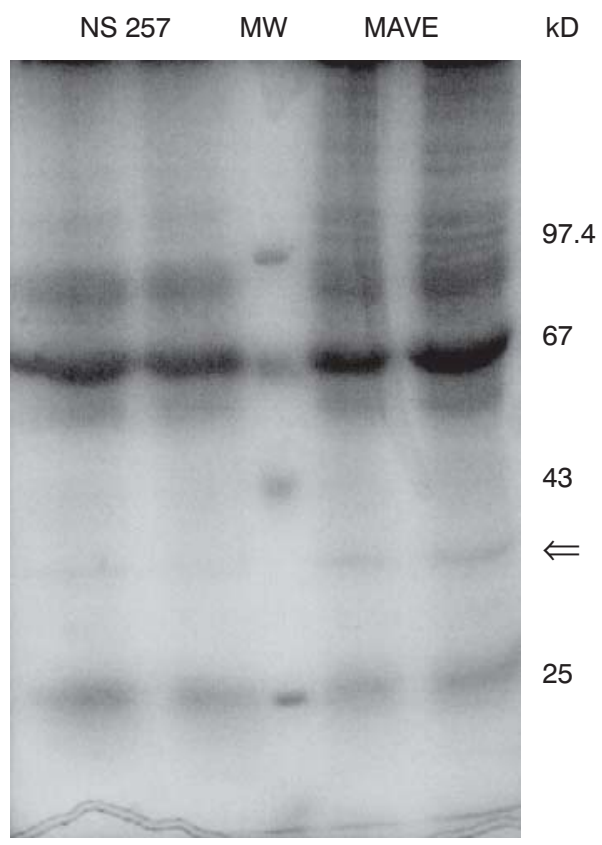

Figure 5. Two-dimensional SDS-PAGE of PrV virus proteins 
checked by means of binding reaction between separated hybridoma supernatants and ascite liquids. VAM 4.1 and VAM 5.1 antibodies showed reactivity with proteins having molecular weights of $120,67,58,43$ and $35 \mathrm{kD}$ for MAVE strain. Hybridoma supernatant VAM 2.1 showed explicit reactivity with MAVE virus strain. The analysis of the Western blot assay results for NS 257 strain showed the presence of four strips to which 120,67, 58 and $35 \mathrm{kD}$ immunoglobulins were linked. VAM 2.1 antibody explicitly reacted with clearly defined strips, while VAM 4.1 had the weakest reaction, binding to NS 257 antigen proteins.

\section{DISCUSSION}

Aujeszky's disease caused by PrV virus is present in many countries of the world. Large economic losses worldwide prompted researches to find out fast and simple methods to detect the causative agents for Aujeszky's disease (Wittmann, 1986). In the past period one of the most frequently used serological methods was ELISA (Eloit et al., 1989; Qvist et al., 1990). This assay, however, is not reliable in all cases, so it is necessary to check the results by other methods such as dot ELISA and Western blot (Yoshida and Tsuda, 1998; Abolhassani, 2000; Belo et al., 2004; Sulimenko and Draber, 2004).

In this study we used specially produced monoclonal antibodies for PrV MAVE strain and PrV NS 257 strains. Successfully obtained monoclonal antibodies from hybridoma cells were used for further characterization. According to literature data, Kohler and Milstein (1975) obtained 3\% clones from a total of 33 fusion mixtures. The increased production of clones does not automatically mean the successful production of specific antibodies. For example, Zaane et al. (1984) produced $60-70 \%$ clones out of which only a few were capable of producing antibodies. In our primary experiments, from 95 produced fusion mixtures only $9.5 \%$ of positive hybridoma cells supernatants were obtained. Preliminary tests roughly indicated the existence of hybridoma from undiluted samples of supernatants. They were used to standardize the ELISA assay performance conditions. In repeated ELISA assays, on the basis of detected activities four hybridoma cultures were selected. The selected reactant concentration (antigens and antibodies) was purified by affinity chromatography in three different antigen concentrations with a selected hybridoma supernatant. Analysis of ELISA assays singled out VAM 2.1 hybridoma which showed a higher level of activity in comparison to three other hybridomas. Comparison of the results of binding activity with each of the two antigens leads to the conclusion that this immunoglobulin shows somewhat higher affinity for NS 257 viral antigen.

On the other hand, dot ELISA assay, due to its simplicity and ease of performance, is more frequently used than other immuno-enzyme assays. The literature data indicate that the quantities of immunoglobulin from $1 \mathrm{ng} / \mathrm{mL}$ to $50 \mathrm{ng} / \mathrm{mL}$ were sufficient to establish reactions with appropriate antigens. These quantities are smaller than those necessary for ELISA assay (Arce et al., 2002; Sulimenko and Draber, 2004). Our experiments with both PrV viral antigens bonded to PVDF membranes showed minimal quantities of bound 
Acta Veterinaria (Beograd), Vol. 57. No. 5-6, 441-451, 2007.

Marković Ljiljana et al.: Production and characterization of

monoclonal antibodies specific for pseudorabies virus

immunoglobulin (2.58 to $165 \mathrm{ng} / \mathrm{mm}^{2}$ ) and comply with literature data (Fleming and Pen, 1988). Comparative review of the obtained results showed higher values of binding of the obtained monoclonal antibodies to the wild strain (NS 257) in comparison with another MAVE strain. VAM 2.1 monoclonal antibody showed that a quantity of $2.58 \mathrm{ng} / \mathrm{mm}^{2}$ is sufficient to establish a visible reaction with both tested antigen strains. This method confirmed former findings with respect to the activity of this antibody and its applicability from the supernatant itself. To find out the activities of the remaining three immunoglobulins it is necessary to have much higher concentrations.

Affinity purification method has been used by many researchers in order to obtain pure immunoglobulins that retained their specific binding affinity (Yoshida and Tsuda, 1998; Morenko et al., 1999; Abolhassani, 2000). Based on literature data we have purified MAbs from hybridoma supernatants and ascitic fluid on Protein G/Sepharose 4FF. Thus, obtained immunoglobulins of IgG class were tested by ELISA, confirming their specific binding activity.

The separated envelope proteins were tested in different electrophoretic conditions and various gel concentrations (8\%, 10\%, and $12 \%)$. Comparative analyses on $10 \%$ polyacrylamide gel (SDS-PAGE) showed unequal presence of protein strips in both antigen strains. In MAVE strain a larger number of strips was detected in the region of higher molecular weights and one poorly visible in the 40 kD strip.

Quite a number of researchers applied Western blot assay in their studies due to its sensitivity and specific binding reactivity to PVDF membrane (Abolhassani 2000; Arce et al., 2002;). The so obtained results show specific points of binding of monoclonal antibodies and antigens. This special method enables the characterization and selective choice of monoclonal antibodies (Qvist et al., 1989; Nakamura et. al., 1990).

Nakamura et al. (1990) detected a specific binding activity of one monoclonal antibody to $230 \mathrm{kD}$ protein, while in the other one discovered two determinant points of binding to $70 \mathrm{kD}$ and $60 \mathrm{kD}$ proteins. During this experiment four selected MAbs recognized specific points of binding to electrophoretically separated proteins of the envelopes of PrV viral strains (MAVE and NS 257). The analyses of the results of binding of three monoclones showed the presence of several strips having different molecular weights and intensity. Comparative analyses of the binding process did not show the difference between MAVE and NS 257 strains. The results of VAM 6.1 binding indicated the presence of a immunodominant region that was unnoticeable in three other monoclonal antibodies.

In this experimental work the produced monoclonal antibodies were tested by applying several testing methods: ELISA, dot ELISA and Western blot assays. Comparison of the results shows compatibility, with no significant differences in reactions of vaccinal and wild strains. The changes perceived and stated in this study should be the commencement of further researches with the view to detect Aujeszky's disease and differentiate between naturally infected and vaccinated animals. 


\section{ACKNOWLEDGEMENT:}

The authors wish to thank Prof. dr M. Čolić (Military medical Academy) for its contribution in the production of the monoclonal antibodies. We are greatful to dr N. Dovezenski (Institute of Medical Science) for his help and critical suport throughout this study.

This study was supported by Serbian Ministry of Science and Environment Protection (Grant No 143030 b to E.R.I)

Address for correspondence:

Dr. Ljiljana Marković

Institute of Nuclear Science Vinča

Mihajla Petrovića Alasa 12-14

P.O. box 522

11000 Belgrade, Serbia

ljiljanam@vin.bg.ac.yu

\section{REFERENCES}

1. Abolhassani $M, 2000$, Identification of two epitopes on the outer surface protein of the lyme disease spirochete Borrelia burgdorferi, Iran Biomed, 4, 7-12.

2. Arce C, Moreno A, Millan Y, Martin de las Mulas J, Llanes D, 2002, Production and characterization antibodies against dog immunoglobulin isotypes, Vet Immun Immunopath, 6663, 1-11.

3. Belo EFT, Coutinho LMCC, Ferraz AS, De Gaspari EN, 2004, Production of monoclonal antibody to subtype 9 of Neisseria meningitidis and the distribution of this subtype in Brazil, Braz $\mathrm{J}$ Infect Dis, 8, 407-18.

4. Butle JE, 1991, Immunochemistry of Solid-Phase Immunoassay (Hardcover), Book, ISBN 0849353947, 319.

5. Cordosa MJ, Hooi TP, Shaari NS, 1988, Development of a dot enzyme immunoassay for denge 3: a sensitive method for the detection of entidengue antibodies, $J$ Vir Meth, 22, 81-8.

6. Draber $P, 1991$, Quantification of proteins in sample buffer for sodium dodecyl-polyacrylamide gel electrophoresis using colloidal silver, Electrophoresis, 12, 453.

7. Eloit M, Fargeaud D, Vannier P, Toma B, 1989, Development of an ELISA to differentiate between animals either vaccinated with or infected by Aujeszky's disease virus, Vet Record, 28, 91-4.

8. Fleming JO, Pen JB, 1988, Measurement of the concentration of murine IgG monoclonal antibody in hibridoma supernatants and ascites in absolute unites by sensitive and reliable enzymelinked immunosorbent assays (ELISA), J Immun Methods, 110, 11.

9. Kohler G, Milstein C, 1975, Continuous cultures of fused cells secreting antibody of predefined specificity, Nature, 256, 495-7.

10. Laemmli UK, 1970, Cleavage of structural proteins during the assembly of the head of bacteriophage T4, Nature, 227, 680-5.

11. Lowry OH, Rosebrough JN, Farr L, Randall RJ, 1951, Protein measurement with the folin phenol reagents, J Biol Chem, 193, 265-75.

12. Milić SN, Gađanski-Omerović G, Ašanin R, Marković SB, 1994, Separation and purification of outer envelope of P13 virus of calves for the preparation of subunit vaccine, Microb, 31, 7-16.

13. Morenkov OS, Smirnov SV, Vrublevskaya W, 1999, Isolation of mutants of Aujeszky's disease virus with antigenically altered glycoprotein $\mathrm{E}$ by affinity chromatography using monoclonal antibodies, $J$ Virol Method, 77, 101-8.

14. Nakamura T, Ihara T, Nagata T, Ishihama A, Ueda S, 1990, A complement-dependent neutralizing monoclonal antibody against glycoprotein II of pseudorabies virus, Vet Mecrob, 24, 193-8.

15. Roizman B, 1990, The family Herpesviridae: a brief introduction. In: Fields BN, Knipe DM (eds) Virology 2nd ed. Raven Press, New York: 1787-94.

16. Qvist P, Meyling A, Hoff-Jorgensen R, 1990, Detection by Enzyme-linked immunosorbent assay of Aujeszky's disease virus in tissues of infected pigs, J Clin Microb, 28, 383-4. 
Acta Veterinaria (Beograd), Vol. 57. No. 5-6, 441-451, 2007.

Marković Ljiljana et al.: Production and characterization of

monoclonal antibodies specific for pseudorabies virus

17. Sulimenko $T$, Draber $P, 2004$, A fast and simple dot-immunobinding assay for quantification of mouse immunoglobulins in hybridoma culture supernatants, $J$ Immunol Methods, 289, 89-95.

18. Towbin H, Staehelin T, Gordon J, 1979, Electrophoretic transfer of proteins from polyacrylamide gels to nitrocellulose sheets: procedure and some applications, Proc Natl Acad Sci USA, 76, 4350-4.

19. Yoshida K, Tsuda $T, 1998$, Rapid detection of antigenic diversity of akabane virus isolates by dot immunobinding assay using neutralizing monoclonal antibodies, Clin Diagnost Lab Immunol, 5, 192-8.

20. Wittmann G, 1986, Aujeszky's disease, Rev Sci Tech Int Epiz, 5, 959-77.

21. Van Zaane D, ljzerman J, 1984, Monoclonal antibodies against bovine immunoglobulins and their use in isotype-specific ELISA's for rotavirus antibody, J Im Meth, 72, 427-41.

\title{
DOBIJANJE I KARAKTERIZACIJA MONOKLONSKIH ANTITELA SPECIFIČNIH ZA PSEUDORABIES VIRUS
}

\author{
MARKOVIĆ LJILJANA, AŠANIN RUŽICA, RADOJIČIĆ SONJA i ISENOVIĆ ESMA
}

\section{SADRŽAJ}

Monoklonska antitela (MAbs) specifična za Pseudorabies virus (PrV) dobijena su fuzijom ćelija mijelocita P3x-Ag8.653 i splenocita miševa BALB/c koji su imunizovani suspenzijama sojeva MAVE (Morbus Aujeszk'y virus Ercegovac) i NS 257 (soj 257 Novi Sad). U 95 uzoraka supernatanata hibridnih ćelija primenom ELISA metode ispitivano je prisustvo antitela specifičnih za sojeve virusa (MAVE i NS 257). Navedenom metodom otkriveno je deset monoklonskih antitela koja su specifično reagovala sa oba soja virusa. Izdvojena četiri monoklonska antitela označena kao VAM 2.1, VAM 4.1, VAM 5.1 i VAM 6.1, radi dalje analize, prečišćena su metodom hromatografije na koloni protein G Sepharosa 4FF, a zatim ponovo ispitana ELISA metodom. Karakterizacija izdvojenih MAbs za navedene viruse urađena je metodama elektroforeze SDS-PAGE i Westernblott. Dot-blott metodom iz supernatanata hibridnih ćelija i ascitne tečnosti kvantifikovana su monoklonska antitela VAM 2.1, VAM 4.1, VAM 5.1 i VAM 6.1. Monoklonsko antitelo VAM 2.1 pokazalo je visok nivo aktivnosti u reakciji sa oba soja virusa. Analizom proteinskog profila virusnog omotača soja MAVE detektovan je glikoprotein molekulske mase 40 kD. Ova ispitivanja su ukazala da monoklonska antitela specifična za sojeve PrV mogu da se primene u otkrivanju Aujeskijeve bolesti. 